
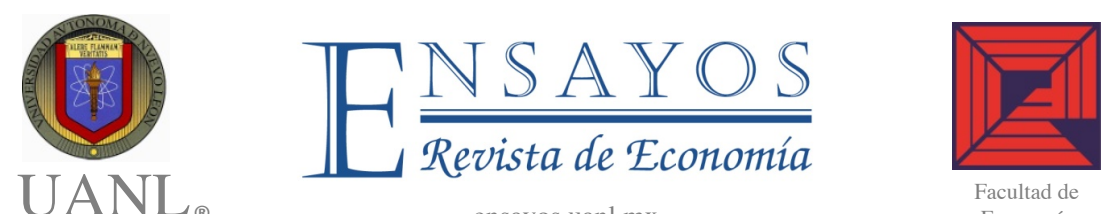

\title{
The Role of Cognitive and Personality Characteristics in Timely Microcredit Repayment: Evidence from a Survey Conducted by Provident, Mexico
}

El papel de las características cognitivas y de personalidad en el pago oportuno de microcréditos: Evidencia de una encuesta realizada por Provident, México

\author{
Sonia Di Giannatale* \\ Daniel Ventosa-Santaulària ${ }^{*}$ \\ María José Roa ${ }^{\ddagger}$ \\ Alexander Elbittar* \\ Darío Trujano§
}

\begin{tabular}{|c|c|}
\hline Article information & Abstract \\
\hline $\begin{array}{l}\text { Received: } \\
\text { 16 January } 2019 \\
\text { Accepted: } \\
19 \text { February } 2020\end{array}$ & $\begin{array}{l}\text { Sustainability of microfinance institutions depends, } \\
\text { among other factors, on having appropriate repayment } \\
\text { levels. This article's contribution to existing literature is } \\
\text { the analysis of the role of a personality trait named "grit" } \\
\text { in individual microcredit repayment decisions, alongside }\end{array}$ \\
\hline $\begin{array}{l}\text { Keywords: } \\
\text { Microcredit repayment; } \\
\text { Personality traits; Grit; } \\
\text { Cognitive } \\
\text { characteristics; Time and } \\
\text { risk preferences }\end{array}$ & $\begin{array}{l}\text { This study is based on a survey of a sample of clients at } \\
\text { 'Provident México', a formal microfinance institution that } \\
\text { provides personal loans in vulnerable communities in } \\
\text { Puebla, Mexico. We find evidence that, generally, older } \\
\text { individuals possessing higher levels of grit and a tendency } \\
\text { toward short term present bias are more likely to show no } \\
\text { delays in loan repayments. Cognitive characteristics are } \\
\text { inversely related to paying microcredits on time. } \\
\text { Refinancing incentives does not play a key role in timely } \\
\text { microcredit repayment, a result that is contrary to related } \\
\text { literature but consistent with our finding that individuals } \\
\text { in this sample that do not have delays in repayments are } \\
\text { characterized by showing a short term present bias. }\end{array}$ \\
\hline
\end{tabular}

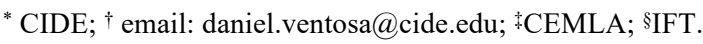

ISSN Electrónico: 2448-8402 | ISSN Impreso: 1870-221X | @2020 Los autores @]

Citar asi: Sonia Di Giannatale, Daniel Ventosa-Santaulària, Maria José Roa, Alexander Elbittar and Darío Trujano (2020). The Role of Cognitive and Personality Characteristics in Timely Microcredit Repayment: Evidence from a Survey Conducted by Provident, Mexico. Ensayos Revista de Economía, 39(1), 1-20, http://dx.doi.org/10.29105/ensayos39.1-1 


\begin{tabular}{|c|c|}
\hline $\begin{array}{l}\text { Información del } \\
\text { artículo }\end{array}$ & Resumen \\
\hline $\begin{array}{l}\text { Recibido: } \\
16 \text { enero } 2019 \\
\text { Aceptado: } \\
19 \text { febrero } 2020\end{array}$ & $\begin{array}{l}\text { La sostenibilidad de las instituciones microfinancieras } \\
\text { depende, entre otros factores, de tener niveles apropiados } \\
\text { de repago. Este trabajo contribuye a la literatura existente } \\
\text { al analizar el papel de un rasgo de personalidad } \\
\text { denominado "diligencia" ("grit" en inglés) en las }\end{array}$ \\
\hline $\begin{array}{l}\text { Clasificación JEL: } \\
\text { D12; D14 } \\
\text { Palabras clave: } \\
\text { Reembolso de } \\
\text { microcréditos; Rasgos de } \\
\text { personalidad; } \\
\text { Determinación; } \\
\text { Características } \\
\text { cognitivas; Preferencias } \\
\text { temporales y de riesgo }\end{array}$ & $\begin{array}{l}\text { decisiones de repago de microcréditos individuales, junto } \\
\text { con las habilidades cognitivas y las preferencias de tiempo } \\
\text { y riesgo. Este estudio se basa en una encuesta aplicada a } \\
\text { una muestra de clientes en 'Provident México', una } \\
\text { institución formal de microfinanzas que ofrece préstamos } \\
\text { personales en comunidades vulnerables en Puebla, } \\
\text { México. Los resultados obtenidos indican que, en general, } \\
\text { las personas mayores que poseen niveles más altos de } \\
\text { diligencia, y que tienden a tener un sesgo por el corto } \\
\text { plazo, tienen más probabilidades de no mostrar retrasos en } \\
\text { el repago de los préstamos. Las características cognitivas } \\
\text { están inversamente relacionadas con el pago de las deudas } \\
\text { a tiempo. Los incentivos de refinanciamiento no } \\
\text { desempeñan un papel clave en el repago a tiempo del } \\
\text { microcrédito, resultado contrario a la literatura sobre este } \\
\text { tema pero que es acorde con el resultado del sesgo por el } \\
\text { corto plazo que muestran los individuos de esta muestra } \\
\text { que no tienen retrasos en sus pagos. }\end{array}$ \\
\hline
\end{tabular}

\section{Introduction}

This paper analyzes microcredit repayment decisions of a sample of individuals to whom 'Provident México' (hereafter Provident), a formal microfinance institution (MFI) based in Puebla (Mexico), had granted a simple door-to-door personal loan. Specifically, the objective of this research is to examine the hypothesis that cognitive characteristics as well as personality traits and preferences play a role in microcredit repayment behavior. This hypothesis is based on recent personality and cognition theories, and the relevance of its examination is to gain understanding on the determinants of vulnerable individuals' microcredit repayment behavior for the sake of the well-being of individuals per se and of the sustainability of MFIs.

MFIs represent the only source of access to formal credit for many individuals in vulnerable socioeconomic conditions around the world (Armendáriz de Aghion and Murdoch, 2010). Despite its importance, evidence of the impact of microfinance on poverty reduction in developing countries has been inconclusive (Hermes and Lensink, 2011). Only recently evaluations of microfinance programs using the randomized-controlled-trials (RCT) approach have been undertaken. The RCT methodology is widely used in development economics for its identification advantage, and it has received important recognition with the awarding of the Nobel Prize in Economics in 
2019 to Abhijit Banerjee, Esther Duflo, and Michael Kremer for using this approach with the objective of alleviating poverty, including the design and evaluation of several microfinance initiatives. Evidence has been reported that there are interventions where it is observed that microfinance enhances consumption smoothing and expenditure in durable goods (Banerjee et al., 2015), and investment in income-generating activities (Augsburg et al., 2015; Crépon et al., 2015). Besides the good news, we have studies that report cases in which microcredits do not show to have significative impacts on poverty relief (Angelucci et al, 2015; Attanasio et al., 2015).

On the other hand, lending to the poor is costly due to elevated transaction and information costs, which contributes to the high interest rates that MFIs charge their clients, and MFIs must ensure an appropriate repayment rate to be sustainable (Bauer et al., 2012; Nawai and Shariff, 2012; Baklouti, 2013; Van den Berg et al., 2015). However, problems such as excessive professionalization of MFIs and distancing from the original joint-liability loan format; clients' over-indebtedness and its stressful consequences; and repayment problems (Attanasio, et al., 2015; Banerjee et al., 2015), have cast a negative light on microfinance as a vehicle for poverty alleviation.

The microfinance sector in Mexico began operating in the decade of the 50's with the creation of Sociedad de Cooperativas de Ahorro y Crédito (Savings and Credit Cooperatives Society), and since then this sector has experienced significant growth. Even though the interest rates that Mexican MFIs charge their clients have shown a decreasing trend in recent years, they are still higher than those charged by MFIs in other Latin American countries. The reason seems to lie in the small average size of microcredits which implies that MFIs in Mexico face high operation costs and lack of efficiency in resource management (Cotler, 2013; Aldasoro, 2017). As pointed out by Griffin and Husted (2015), the sustainability of an MFI depends on its repayment rate, and, given that most of MFIs operating in Mexico offer group-base-lending, factors such as social sanctions are of relevance when explaining repayment. However, as mentioned above, Provident offers personal loans and as of 2014, around $70 \%$ of its clients have shown delays in their payments. So, it is reasonable to think that repayment of this type of microcredit is more dependent on personal characteristics than with social issues. The novel aspect of this research is the expansion of the set of personal characteristics, based on recent contributions to the economic literature that will be reviewed in the next section, that might play an important role in timely microcredit repayment.

A survey applied to a random sample of clients of Provident, and information provided by Provident on the microcredit repayment status of this sample of clients are the sources of the dataset analyzed in this paper. The results obtained from the econometric exercise performed here indicate that older individuals 
possessing higher levels of grit and with a tendency toward short term present bias are more likely to not have delays in microcredit repayments. Cognitive characteristics results are inversely related to timely debt repayment. Unexpectedly, refinancing incentives do not play a key role on timely microcredit repayment is played, but this result is consistent with our finding that individuals in this sample that do not have delays in repayment are characterized by showing a short term bias. It is worth observing that most of the studies related to this article, that will be reviewed in the next section, analyze financial decision-making in developed economies, whereas this study is focused on microfinance repayment behavior in a developing economy. Hence, this article's main contribution to the literature is the addition of personality and cognitive measures to the study of the microcredit repayment behavior in a developing economy.

The rest of this paper is organized as follows. The next section presents a review of the relevant literature with the purpose of laying out a conceptual framework to justify the empirical model to be estimated. In the third section, the empirical methodology and analysis of the unit are described. In the fourth section, descriptive statistics of the sample are presented. The formalization of the empirical model and the econometric results are presented in the fifth section. Finally, in the last section, conclusions are outlined and discussed.

\section{Literature review}

This article is related to several strands of the economic literature. First, it contributes to the microcredits' repayment literature, in which a general but not undisputed agreement exists that sociodemographic characteristics are important factors in explaining repayment behavior. Education and income have been shown to be positively correlated to good microfinance repayment behavior (Bhatt and Tang, 2002; Nawai and Shariff, 2012). The evidence on gender has been mixed: some studies find no significant relationship between gender and repayment (D'Espallier et al., 2011), while others find that women, in general, are a better credit risk for MFIs (Armendáriz and Murdoch, 2010).

Second, this study analyzes the importance of refinancing incentives in repayment drawn by studies in microfinance. A group of studies have demonstrated that the structure of the microfinance contracts plays a role in repayment behavior. Without explicit incentives -- such as group liability or the use of non-refinancing threats -- borrowers tend to be at least late on their repayment schedule (Bauer et al. 2012; Nawai and Shariff, 2012; Baklouti, 2013). After evaluating several microfinance experiences around the world, Armendáriz De Aghion and Murdoch (2000) emphasize several mechanisms that help guarantee timely individual credit repayment behaviors and avert some of the lateness endemic in the microloan market. Said mechanisms 
include the implementation of non-financial services, direct monitoring, regular payment programs, and threats of non-refinancing that serve as dynamic incentives.

Third, this work relates to studies that have shown the importance of including cognitive characteristics when explaining individual behaviors. The effect that cognitive characteristics have on a variety of economic and social outcomes has been well documented (Almlund et al., 2011; Borghans et al., 2011). An expanding body of work has found that higher levels of cognitive abilities positively affect financial habits in different ways: lower probability of default, fewer financial errors, and greater sophistication in the use of financial products (Christelis et al., 2010; McArdle et al., 2011; Grinblatt et al., 2011; Agarwal and Mazumder, 2013; Cole and Shastry, 2014). These works primarily suggest that cognitive abilities - and, of these, numerical abilities in particular - are strongly related to making appropriate financial decisions. In addition, there has been evidence of a positive relationship between cognitive abilities and financial literacy, defined by Lusardi and Mitchell (2014) as "people's ability to process economic information and make informed decisions about financial planning, wealth accumulation, debt, and pensions."

Fourth, this article brings together elements of recent studies that have analyzed the role of personality traits in socioeconomic behaviors. Psychologists have sketched a relatively commonly accepted taxonomy of personality traits known as the 'Big Five': Openness to Experience, Conscientiousness, Extroversion, Agreeableness and Neuroticism. Borghans et al. (2011), Almlund et al. (2011), and Heckman and Kautz (2012) reviewed evidence which indicates that these personality traits are as powerful as cognitive abilities in predicting socioeconomic behaviors, and that they are more malleable than cognitive characteristics over the life cycle.

A group of pioneering studies has studied the relationship between personality traits and financial behaviors. Some of these suggest that the presence of a certain sub-facet related to Conscientiousness - named grit or diligence -- can explain wealth accumulation (Ameriks et al., 2003); financial distress (McCarthy, 2011); indebtedness and default frequency (Klinger et al., 2013 a, b); good management of finances (Kaufmann, 2012); investment biases (Jamshidinavid et al., 2012); and savings (Kausel et al., 2016; Roa et al., 2019). In general, grit is considered a measure of both the propensity to plan and perseverance. Concerning microfinance, Klinger et al. (2013 a, b) shows that Conscientiousness and Intelligence have a predictive power similar to that of the usual metrics for evaluating loan repayment, such as credit bureau data, while Honesty relates to willingness to repay a loan. In addition, these authors found that Extroversion is strongly related to high profits, while Agreeableness (positive), Conscientiousness (negative) and Integrity (negative) are weakly 
related. Some of these results are surprisingly stable across a variety of countries, cultures and types of business.

Five risk and time preferences have been recognized by economists to play a central role in financial decisions. In the case of credit behavior, Meier and Sprenger (2010) find that individuals who are present-biased show a higher probability of having credit card debts. Regarding microfinance repayment behavior, there is evidence that non-refinancing threats along with regular payment schedules can help minimize problems of lack of self-control and present-biased preferences (Bauer et al., 2012; Basu, 2016).

Given the concepts and theoretical frameworks that have been explained in the previous paragraphs, the objective at this point is to propose an empirical model to explain the relationship between the probability that an individual repays a microcredit on time (dependent variable) and the following explanatory variables: (i) refinancing incentives: the expectation is that having more than one microcredit with the institution will have a positive effect on the probability of microcredit repayment; (ii) sociodemographic characteristics: it is expected that being a woman, having higher income and educational level, and being older will positively impact the microcredit repayment probability; (iii) conscientiousness (grit), and time and risk preferences: it is important to clarify that the assumption that has been made here, as in several other related studies (Almlund et al., 2011), is that personality characteristics and preferences are complements in explaining several economic behaviors, so they are included as independent explanatory variables. That said, it is expected that being grittier, more patient, and more risk averse all have a positive relationship with the repayment probability; and finally, (iv) cognitive characteristics and financial literacy: higher measured levels of cognitive ability and of financial literacy are expected to be positively related to the microcredit repayment probability.

In the next section, the fundamentals of the empirical methodology employed in this article, i.e., the construction of the measures of grit, cognitive ability and preferences, and the unit of analysis, will be explained.

\section{Methodology and Unit of Analysis}

\subsection{Measuring grit, cognitive ability, and preferences}

The survey included a total of 16 questions and was designed to gather information on the following variables: grit, cognitive characteristics, time and risk preferences, basic financial knowledge, and sociodemographic 
characteristics. ${ }^{1}$ In line with the personality traits literature, the working hypothesis is that grit must be one of the components of the set of attributes that comprise an individual's sense of discipline when making long-term financial decisions. A gritty or diligent individual might consider financial resources to be a means to an end (the basic definition of money) and may want to ensure a constant stream of monetary resources.

The Short Grit Scale (Grit-S) (Duckworth and Quinn, 2009), save one question, is used to obtain a measure of grit. The first seven questions of the questionnaire are taken and divided into two groups: Passion for Long-term Goals (questions 1, 3, 5, and 6), and Perseverance of Effort (questions 2, 4, and $7)$. Then, the scores for each answer are added up and the sum is divided the result by 7 to obtain the individual's grit indicator. Grit-S is a continuous variable with a maximum value of 5 (extraordinary Grit level), and a minimum of 1 (absence of Grit).

The level of an individual's cognitive ability was measured based on one question (question 9) that is considered standard for this purpose (Frederick, 2005). Financial knowledge was tested with two questions (questions 12 and 13) from the OECD's Financial Literacy questionnaire (OECD INFE, 2011; Lusardi and Mitchell 2014). These questions relate to the calculation of interest rates and to the concept of inflation. The interest rate question is sometimes considered a measure of numerical abilities because it explicitly requires a calculation (Van Rooij et al., 2011; Gerardi et al., 2013). That view is adopted here, hence the interest rate question is considered a measure of numerical abilities. Questions 9, 12 and 13, as well as the level of education (question 14 ), will be used to measure cognitive ability in the econometric analysis.

Information about time and risk preferences was obtained through three questions, one for risk aversion (question 8) and two for time preferences (questions 9 and 10). Finally, three questions about the sociodemographic characteristics of the clients were included in the survey: i) question 14, last school year completed; (ii) question 15, civil status; and (iii) question 16, number of dependents.

\subsection{Unit of Analysis}

The unit of analysis is Provident, a formal microfinance institution based in Puebla (a state close to Mexico City), that grants simple door-to-door personal loans, and which also operates in other parts of the country. To be eligible for a personal loan, Provident requires that the prospective client provide an official ID and proof of address. New clients can apply for personal loans

\footnotetext{
${ }^{1}$ A detailed description of this questionnaire can be found in the On-line Appendix 1.
} 
ranging from 1,000 to 7,500 Mexican pesos (approximately 75.8-568.6 USD). ${ }^{2}$ If the client has a positive credit history, this limit rises to 15,000 pesos per loan. Clients make payments on a weekly basis over a period of up to 31, 41 or 51 weeks. There is also an additional one-time charge that is determined at the beginning of the loan (to cover administrative services, shipping, weekly fee, and value-added tax), which is spread out weekly over the loan's duration. There are no additional charges for late payments. Provident has reported that most of the loans are used to purchase consumer goods or to cover emergencies.

Provident classified its clients into three groups: Current, Low Arrear, and High Arrear. It first decides on an initial date on which to base the client's credit history. Clients who have made all their weekly payments on time since that date are classified as Current; those who have made 1-3 late payments over the period are classified as Low Arrear; and finally, those who have been late in paying on more than four occasions are classified as High Arrear.

Given the socioeconomic characteristics of its clients, Provident expects some degree of lateness in the weekly payments and this expectation is included in the calculation of the service charge the clients must pay for their loans. However, the clients do not pay interest on late payments. Also, Provident provides some incentives to clients who pay their weekly payments on time. For example, a client could receive a refinancing offer. On the other hand, a client is eligible for another loan if he or she meets the following criteria:

1) Person's age must be in the range of $[18,71]$.

2) The previous loan's unpaid balance must be at most $32 \%$.

3) If there is another active client in the household, the total unpaid debt must not exceed $\$ 55,000$ if the collection rate in the previous 13 weeks is lower than $83 \%$; and $\$ 70,000$ otherwise.

Provident offered to obtain 100 completed questionnaires from each group (Current, Low Arrear, and High Arrear), from the total of 2,475 clients that Provident selected as prospective members of our sample. From the initial sample, the total number of complete interviews was 299: 99 Current, 100 Low Arrear, and 100 High Arrear. These interviews were conducted by phone from the Provident's Call Center between January and April 2014. ${ }^{3}$ It must be noted

\footnotetext{
2 The average exchange rate in the period from January to April 2014 was 13.19 Mexican pesos per US Dollar.

${ }^{3}$ The sample is from 2014. We had access to the data a significant while after the sampling was made, and then we had to provide a statistical analysis to Provident, which also took some time. The agreement with Provident was that after the report, we could use the data to write a research paper. At that point, a more detailed analysis was required to take full
} 
that during this period, Provident had a total of 924,858 clients of which $28.2 \%$ were in the Current group, while 56\% and $15.8 \%$ were in the Low and High Arrear groups, respectively. These weights were considered in the regressions.

Finally, Provident provided the following information on the 299 clients who completed the interviews: (i) sociodemographic variables: age; number of children; employment status; gender; verifiable and non-verifiable income; and home, cell phone, and landline ownership; and (ii) financial records: number of loans (history); active loans; monetary amount of active loans; total amount yet to be paid; monetary amount of late payments; and weekly payment.

\section{Descriptive Statistics}

As a first approach to the possible link among credit repayment and the variables of interest, some patterns are outlined here. A more detailed description of these patterns can be found in the On-line Appendix 2. Here are some highlights that can be drawn from analyzing those descriptive statistics:

(i) the probability of belonging to the Current group is slightly higher for an individual who is older than 35 years old, has fewer dependents, is a woman, and has a higher level of non-verifiable income.

(ii) the number of active loans monotonically decreases when moving from the Current group (1.36), Low Arrear group (1.19), and High Arrear group (0.6), in that order.

(iii) Current individuals obtain a Grit scale that is 0.10 times higher, on average, than that of the two other groups and a standard deviation of 5, also 0.7-0.9 times higher.

(iv) there are no significant differences in terms of short- and mediumterm preferences among the groups, except for a noticeable preference for the short-term by the Current individuals. All groups display impatience in their answers preferring to receive their payments sooner rather than later.

(v) there is a negligible difference in the risk aversion level of the three groups, with the exception that the High Arrear group presents a level of risk aversion that is $7 \%$ higher than that of the Low Arrear group.

(vi) the High Arrear group proves to be above average in correct answers to the question that requires a simple interest calculation, and this group also has the highest standard deviation in the answers of this group with

advantage of the dataset and we modified the model specification accordingly; unfortunately, we encountered several technical difficulties in the statistical methodology. Such corrections took us more time than we care to admit. Once we considered that the estimation was appropriate, we asked for the informal opinion of several experts in the field, which was also a lengthier process than initially expected. 
respect to those of the other two groups. Also, the High Arrear group shows the highest frequency of incorrect answers to the question about inflation, though there seems to be no significant difference with respect to the other two groups.

(vii) all of the answers to the question included to measure cognitive ability were incorrect and diverse. So, deviations with respect to the correct answer were calculated, and it is noticeable that, on average, people in the High Arrear group are closest to the correct answer, while individuals in the Current group are farthest from the correct answer.

(viii) the difference between the High and Low Arrear groups in terms of Level of Schooling is not significant and, surprisingly, the Current group shows the highest proportion of individuals that have an Elementary School education or less.

\section{Econometric Analysis and Results}

\subsection{Empirical Model}

As in Heckman et al. (2006), the empirical model that is analyzed in this paper is based on the Roy model (Roy, 1951). To be precise, three microcredit repayment levels, following the classification devised by Provident, are used: Current, Low Arrear and High Arrear. Let $c$ be an individual's chosen microcredit repayment level, and $I_{c}$ the individual's net profit associated with each microcredit repayment level. Hence, the empirical model is:

$$
I_{c}=\beta_{c} X_{c}+\alpha_{c}^{P} f^{P}+\alpha_{c}^{C} f^{C}+\alpha_{c}^{N} f^{N}+e_{c},
$$

$c \in\{$ current, low arrear, high arrear\}: microcredit repayment level,

where $X_{c}$ is a vector of observed sociodemographic characteristics of the individual that affect microcredit repayment behavior, $\beta_{c}$ is its vector of parameters, $f^{P}$ is the individual's time and risk preference, $f^{C}$ is the individual's level of cognitive ability, $f^{N}$ is the individual's Grit Scale; $\alpha_{c}^{P}, \alpha_{c}^{C}$ and $\alpha_{c}^{N}$ are parameters associated with time and risk preferences, cognitive ability and Grit Scale score, respectively, and $e_{c}$ represents an idiosyncratic component assumed to be independent from $X_{c}, f^{P}, f^{C}$ and $f^{N}$. It is assumed that time and risk preferences, cognitive ability, and Grit Scale are independent, as mentioned in the last paragraph of the Literature Review.

An individual chooses his or her microcredit repayment level such that:

$$
D_{c}=\operatorname{argmax}\left\{I_{c}\right\}_{c \in\{\text { current,low arrear,high arrear }\}},
$$

where $D_{c}$ denotes the individual's choice. Equations (1) and (2) produce a standard discrete choice model with a structure factor (Heckman, 1981). 
Following Heckman et al. (2006), $f^{P}, f^{C}$ and $f^{N}$ can be interpreted as approximations to the basic parameters of preferences, cognitive ability, and personality traits. In doing so, it is assumed that these concepts play a complementary role in explaining the results for microcredit repayment behavior (Almlund et a1., 2011; Becker et al., 2012; Rustichini et al., 2016). Possible directions of causality are not taken into consideration here.

\subsection{Results}

The model is estimated as a weighted ${ }^{4}$ ordered logistic model (ordered logit, for short). ${ }^{5}$ The dependent variable was the classification of the client in the group Current, Low or High, as a function of late payments. The model is parametrized as:

$$
\log \left(\frac{P(G \leq g)}{P(G>g)}\right)=\beta_{g 0}+\beta X_{C}+\alpha^{P} f^{P}+\alpha^{C} f^{C}+\alpha^{N} f^{N}
$$

where $P(G \leq g)$ is the probability of belonging to the group $\mathrm{g}$ or lower (Current $<$ Low $<$ High). The model is based on the proportional odds assumption, which allows for calculating the same coefficients for every group. In this regression, the choosen variable $D_{c}$ is modeled as a random variable with higher probability for late payments as a function of a latent variable that can be interpreted as $I_{c}$. Note that in this parametrization we are considering that the parameters are equal across groups, except for the intercept. This implicitly assumes that the effects are equal, and the final decision depends only on the level of covariates. This setting allows to analyze the variables of interest at the population level. The proportional odds assumption was evaluated graphically, and the Brant test cannot reject this hypothesis. The result of this analysis is presented in the online appendix.

\footnotetext{
${ }^{4}$ The weights, provided by Provident, are: Current $28.2 \%$, Low arrear $56.0 \%$, and High arrear $15.8 \%$.

${ }^{5}$ An Ordered Logit model (o-logit) is a regression model particularly well suited for ordinal dependent variables, such as the one in this study (Current/Low/High arrear), where the distance between adjacent categories is unknown. The variable has been categorized incrementally (Current $<$ Low $<$ High arrear). We compared Ordered Logit (o-logit) results with those of an Ordered Probit (o-probit), a model also well suited for this type of dependent variable (the latter assumes a cumulative distribution function of the standard normal distribution instead of that of a logistic distribution in a o-logit model). The statistical results of the o-logit model were far better than those of the o-probit (results available upon request). The multinomial logit and the multinomial probit models were discarded because the outcomes of the dataset must be ordered (ranked), and these models seem better suited for categorical data which cannot be ordered in any meaningful way. Being the o-logit a particular case of the multinomial logistic regression, the later model could have been an option. Nonetheless, the results of the former model are satisfactory, and the more sophisticate option was not considered necessary. Similarly, the cumulative logit regression was not considered as it is more limited than the o-logit.
} 
The primary goal is to explain the effects of each factor or concept on the response probability (belonging to a specific group, i.e., Current, Low or High). Given that the latent variable does not have a well-defined unit of measurement, the magnitudes of each estimated parameter cannot be considered meaningful. As this is well known in the literature, we estimate the partial effect of roughly continuous variables on the response probability. These are referred to as marginal effects.

The measurement of cognitive ability deserves a further comment. The latter can be imperfectly proxied or measured through questions 9 (baseball quad), 12 and 13 (financial knowledge), and 14 (level of education); the rather poor performance of the respondents to questions 9,12 , and 13 leads us to suspect that, although informative, the aforementioned questions are not perfect measures of cognitive ability. Therefore, a cognitive ability index, CA1, is built to maximize the information via a Principal Component Analysis (PCA), using the eigenvalues (weights). ${ }^{6}$ This approach allows us to avoid having collinearities whilst simultaneously using most of the available information. Out of the four variables included to build the CA1 index, scholarship (question 14) and interest rate or numerical ability (question 13) bear the most important weight. The index holds almost $30 \%$ of the total variance of these four variables. ${ }^{7}$ The mean of the variables considered for the regression model can be seen in Table 1 .

\section{Table 1}

Average conditional to groups

\begin{tabular}{|c|c|c|c|c|c|c|c|c|c|c|c|c|c|c|c|}
\hline \multirow{2}{*}{ Group } & \multirow{2}{*}{ Grit } & \multirow{2}{*}{ Short Delay } & \multirow{2}{*}{ Long Delay } & \multirow{2}{*}{ CA1 } & \multirow{2}{*}{ Age } & \multirow{2}{*}{ Active Loans } & \multirow{2}{*}{ Female } & \multirow{2}{*}{$\begin{array}{c}\text { Q9. } \\
\text { Baseball } \\
\text { quad }\end{array}$} & \multirow{2}{*}{$\begin{array}{l}\text { Q12. } \\
\text { Interest }\end{array}$} & \multirow{2}{*}{$\begin{array}{c}\text { Q13. } \\
\text { Inflation }\end{array}$} & \multicolumn{5}{|c|}{ Education ${ }^{*}$} \\
\hline & & & & & & & & & & & Primary & econdary & $\begin{array}{l}\text { High } \\
\text { school }\end{array}$ & College & Grade \\
\hline Current & 2.318 & 0.12 & 0.18 & -0.0544 & 40.1 & 1.3 & $66 \%$ & 56.2 & 5131 & 0.374 & 40 & 32 & 20 & 6 & 1 \\
\hline Low Arrear & 2.217 & 0.24 & 0.24 & 0.0183 & 40.9 & 1.2 & $64 \%$ & 49.7 & 3706 & 0.36 & 33 & 38 & 26 & 3 & 0 \\
\hline High arrear & 2.213 & 0.27 & 0.17 & 0.0355 & 35.4 & 0.6 & $61 \%$ & 41.8 & 4585 & 0.44 & 30 & 32 & 29 & 8 & 0 \\
\hline
\end{tabular}

Nota: ${ }^{*}$ This section displays the quantity of people in each group and each education level.

The main results ${ }^{8}$ can be seen in regression (1) in Table 1. Note that the five covariates are statistically significant at the one percent level. These

\footnotetext{
${ }^{6}$ PCA analysis yields a linear combination of the variables that maximizes the variance, i.e., it maximizes the information subject to a parametric constraint: the sum of the squared weights must be equal to 1 .

7 The weights were: -0.1413 (question 9), -0.0842 (question 12), -0.6754 (question 13), and 0.7188 (scholarship). The complete analysis is included in the appendix.

${ }^{8}$ The data and the code to estimate our econometric results can be found in the On-line Appendix 3.
} 
regressions consider the weights of the proportion of the groups in the population; however, the conclusion is the same as those of the regression that does not consider the weights as can the noticed in regression (1) of Table 5. Adding the weights provide more accurate estimates of the coefficients.

\begin{tabular}{ccc}
\multicolumn{3}{c}{ Table 2 } \\
Regressions Considering Weights \\
\cline { 2 - 3 } & \multicolumn{2}{c}{ Dependent Variable } \\
\cline { 2 - 3 } Grit & $-0.446^{* * *}$ & $(2)$ \\
& $(0.044)$ & $-0.528^{* * *}$ \\
Short Delay & $0.919^{* * *}$ & $(0.046)$ \\
& $(0.058)$ & $0.781^{* * *}$ \\
Long Delay & $-0.448^{* * *}$ & $(0.059)$ \\
& $(0.057)$ & $-0.364^{* * *}$ \\
CA1 & $0.100^{* * *}$ & $(0.019)$ \\
& $(0.019)$ & $0.146^{* * *}$ \\
Age & $-0.018^{* * *}$ & $(0.019)$ \\
& $(0.002)$ & $-0.012^{* * *}$ \\
Active loans & & $(0.002)$ \\
& & $-1.550^{* * *}$ \\
AIC & 18973.63 & $(0.039)$ \\
BIC & 19024.08 & 17317.37 \\
Observations & 9972 & 17375.03 \\
\hline \hline
\end{tabular}

Source: own elaboration.

Relevant inference (sign and magnitude) should nonetheless be drawn from the marginal effects, which can be obtained for each arrear. The marginal effects of regression (1) are shown in Table 2.

Table 3

Marginal Effects (1)

\begin{tabular}{cccc}
\hline \hline & Current & Low Arrear & High arrear \\
\hline Grit & 0.087 & -0.028 & -0.059 \\
Short Delay & -0.156 & 0.012 & 0.144 \\
Long Delay & 0.093 & -0.039 & -0.054 \\
CA1 & -0.019 & 0.006 & 0.013 \\
Age & 0.003 & -0.001 & -0.002 \\
\hline
\end{tabular}

Source: Own elaboration. Note: All marginal effects are significant at the $1 \%$ level. 
Notice that all the marginal effects are statistically different from zero and have the expected sign in all but one case, cognitive ability. From our econometric results, we can draw the following conclusions.

Firstly, the probability of belonging to the Current group:

(i) Increases $8.7 \%$ the grittier the individual is.

(ii) Decreases $15.6 \%$ the more present-biased in the short term (Short Delay) the individual is [Question 10]

(iii) Increases 9.3\% the more present-biased in the medium term (Long Delay) the individual is, [Question 11]

(iv) Decreases $1.9 \%$ the higher cognitive ability (CA1) the individual shows, and

(v) Increases $0.3 \%$ the older the individual is.

Secondly, the probability of belonging to the Low arrear (High arrear-in parenthesis) group:

(vi) Decreases $2.8 \%(-5.9 \%)$ the grittier the individual is.

(vii) Increases $1.2 \%(14.4 \%)$ the more present-biased in the short term (Short Delay) the individual is [Question 10].

(viii) Decreases 3.9\% (5.4\%) the more present-biased the individual in the medium term (Long Delay) is, [Question 11].

(ix) Increases $0.6 \%(1.3 \%)$ the higher cognitive ability (CA1) the individual shows, and

(x) Decreases $0.1 \%(0.2 \%)$ the older the individual is.

\subsection{Including refinancing incentives}

As a second econometric exercise, a regression similar to the previous one is run but including a variable that measures the number of active credits the individuals have with this institution. The regression estimates appear in Table 1 , regression (2). Note again that the numerical values and the sign remain unchanged. The marginal effects are barely affected, see Table 4 .

Note that age becomes less important and being present-biased now affects positively via question 10 the probability of belonging to the Low Arrear group (again, the effect is rather small). The interesting part is that, when the individual is participating in only one loan, her probability of being in the Current group increases by $25.7 \%$, whilst it has a small effect in the probability of belonging to the Low Arrear group (-6.2\%) and the probability of belonging to the High Arrear group diminishes by $19.6 \%$. 
Table 4

Marginal Effects (2)

\begin{tabular}{llll}
\hline \hline & Current & Low Arrear & High arrear \\
\hline Grit & 0.088 & -0.021 & -0.067 \\
Short Delay & -0.113 & -0.002 & 0.0115 \\
Long Delay & 0.064 & -0.022 & -0.042 \\
CA1 & -0.024 & 0.006 & 0.018 \\
Age & 0.002 & $<0.001$ & -0.002 \\
Active loans & 0.257 & -0.062 & -0.196 \\
\hline
\end{tabular}

Source: own elaboration.

Several robustness checks ( 4 control regressions to be precise, labeled Control $1,2,3,4)$ were performed, and the results are presented in Table 5. Regressions (1) and (2) in Table 4 are identical to those in Table 1 except that the population weights (of current, low and high arrear) are not considered. The rest of the regressions consider population weights. In regression (3) the variable Age is excluded, in (4) CA1 is excluded, in (5) Long delay is excluded, in (6) Short Delay is excluded, and in (7) Grit is excluded. The estimated parameters and their sign remain unchanged in every robustness check.

\section{Discussion and Conclusions}

The main findings of the paper are as follows. First, a grittier, more presentbiased, and older individual is less likely to delay their loan repayments. That older individuals repay on time is expected. The grit result is in line with related literature that highlights the key role of conscientiousness and its subfacets in desirable economic and financial decision-making (Eskreis-Winkler et al., 2014). Despite having only recently been integrated within the literature on financial decision-making, personality traits seem to constitute a key element in explaining financial behaviors, as they do in other social and economic behaviors. For future research, we plan to extend our analysis and questionnaire to the Big Five and lower-label facets of each one, in order to obtain a more comprehensive view on the role of personality traits in financial decisions.

The time preference result is also consistent with related literature in the sense that there is evidence that people who have microcredits tend to be presentbiased (Meier and Sprenger, 2010; Bauer et al., 2012). However, a temporal inconsistency known as hyperbolic discounting (Laibson, 1997) is observed here: the individuals who belong to the Current group are present-biased in the short-term while more patient in the medium term. Besides this, as contradictory as it might seem, we believe that a more diligent and present- 
biased individual in the short-term has higher probability of a timely credit repayment. This finding supports the idea that personality traits and time preferences play a complementary role in explaining individuals' life outcomes (Almlund et al., 2011; Becker et al., 2012; Rustichini et al., 2012). While the possible relationship between preferences and personality traits is beyond the scope of this paper, it should be explored in future research.

\section{Table 5}

\section{Regressions Considering Weights}

\begin{tabular}{|c|c|c|c|c|c|c|c|}
\hline & \multicolumn{7}{|c|}{ Dependent Variable } \\
\hline & \multicolumn{2}{|c|}{ Without Weights $^{1}$} & \multicolumn{4}{|c|}{ Weighted } & \multirow[b]{2}{*}{ (7) } \\
\hline & (1) & (2) & (3) & (4) & (5) & (6) & \\
\hline Grit & $\begin{array}{l}-0.465^{*} \\
(0.240)\end{array}$ & $\begin{array}{l}-0.476^{*} \\
(0.259)\end{array}$ & $\begin{array}{c}-0.498 * * * \\
(0.045)\end{array}$ & $\begin{array}{c}-0.503 * * * \\
(0.045)\end{array}$ & $\begin{array}{c}-0.538 * * * \\
(0.046)\end{array}$ & $\begin{array}{c}-0.519 * * * \\
(0.045)\end{array}$ & \\
\hline Short Delay & $\begin{array}{c}1.009 * * * \\
(0.316)\end{array}$ & $\begin{array}{c}0.723 * * \\
(0.333)\end{array}$ & $\begin{array}{c}0.752^{* * *} * \\
(0.059)\end{array}$ & $\begin{array}{c}0.760 * * * \\
(0.059)\end{array}$ & $\begin{array}{c}0.580 * * * \\
(0.050)\end{array}$ & & $\begin{array}{c}0.769 * * * \\
(0.059)\end{array}$ \\
\hline Long I & $\begin{array}{l}-0.609 * \\
(0.319)\end{array}$ & $\begin{array}{l}-0.343 \\
(0.335)\end{array}$ & $\begin{array}{c}-0.321 * * * \\
(0.059)\end{array}$ & $\begin{array}{c}-0.392 * * * \\
(0.059)\end{array}$ & & $\begin{array}{c}0.065 \\
(0.049)\end{array}$ & $\begin{array}{c}-0.389 * * * \\
(0.059)\end{array}$ \\
\hline CA1 & $\begin{array}{c}0.090 \\
(0.102)\end{array}$ & $\begin{array}{c}0.133 \\
(0.108)\end{array}$ & $\begin{array}{c}0.138^{* * *} * \\
(0.019)\end{array}$ & & $\begin{array}{c}0.154 * * * \\
(0.019)\end{array}$ & $\begin{array}{c}0.134 * * * \\
(0.019)\end{array}$ & $\begin{array}{c}0.130^{* * *} \\
(0.019)\end{array}$ \\
\hline Age & $\begin{array}{c}-0.027 * * * \\
(0.009)\end{array}$ & $\begin{array}{l}-0.017^{*} \\
(0.010)\end{array}$ & & $\begin{array}{c}-0.012 * * * \\
(0.002)\end{array}$ & $\begin{array}{c}-0.011 * * * \\
(0.002)\end{array}$ & $\begin{array}{c}-0.011 * * * \\
(0.002)\end{array}$ & $\begin{array}{c}-0.011 * * * \\
(0.002)\end{array}$ \\
\hline Active & & $\begin{array}{c}-1.772 * * * \\
(0.223)\end{array}$ & $\begin{array}{c}-1.576 * * * \\
(0.039)\end{array}$ & $\begin{array}{c}-1.531 * * * \\
(0.039)\end{array}$ & $\begin{array}{c}-1.560 * * * \\
(0.039)\end{array}$ & $\begin{array}{c}-1.579 * * * \\
(0.039)\end{array}$ & $\begin{array}{c}-1.530 * * * \\
(0.039)\end{array}$ \\
\hline AIC & 648.59 & 574.49 & 17370.44 & 17373.04 & 17353.48 & 17490.24 & 17450.48 \\
\hline $\mathrm{BIC}$ & 674.49 & 604.09 & 17420.89 & 17423.49 & 17403.93 & 17540.69 & 17500.93 \\
\hline Observations & 299 & 299 & 9,972 & 9,972 & 9,972 & 9,972 & 9,972 \\
\hline
\end{tabular}

Note: *p $<0.1 ; * * \mathrm{p}<0.05 ; * * * \mathrm{p}<0.01$

1 The first two regressions are equal to regressions (1) and (2) in Table 1 but without considering weights.

The second main finding of this paper is that cognitive ability, while statistically significant, does not explain the probability of belonging to the Current group. Contrary to what we had expected, the lower an individual's cognitive ability, the likelier they are to be in the Current group. This result is also at odds with prevailing ideas in the literature on the subject (Christelis et al., 2010; McArdle et al., 2011; Grinblatt et al., 2011; Agarwal and Mazumder, 2013; Cole et al., 2014). Notwithstanding, Baklouti (2013) found that borrowers with the lowest educational levels exhibit the highest repayment rate, the idea being that clients with a low level of education tend to have fewer financial alternatives, and therefore value the loans they do obtain more highly. This finding brings support to the conclusion of Muhammad Yunus that poor borrowers, who are completely financially excluded, are more trustworthy than rich ones. This might be an explanation for the negative relationship that is found between cognitive characteristics and repayment behavior, particularly in a country with high levels of financial exclusion of the low-income population (Demirgüç-Kunt et al., 2015). 
It should be noted, however, that this result could also be due in part to measurement errors. Specifically, in this sample nobody provided a correct answer to the question included to measure cognitive ability, and the answers to questions included to measure numerical ability (simple interest calculation) and financial literacy (knowledge of the concept of inflation) were not answered correctly by most of the sampled individuals. Although these questions have proved to be appropriate to build valid indicators of cognitive characteristics and financial literacy for individuals in developed economies (Frederick, 2005; Burks et al., 2009; Lusardi and Mitchell, 2014), it is possible that non-verbal IQ tests, such as Raven's Matrices and Digit test, could be more effective at measuring individuals' cognitive ability for developing economies and low-income populations (Arráiz et al., 2015).

Given the nature of survey data, a possible selection bias could be present. In the sample, around $14 \%$ of the people completed the survey; this may be due to the lack of monetary incentives. However, given that the sample was taken from the clients of Provident that were active at the moment of the survey, there is information about who completed the survey and who did not. We found no statistical difference between these two groups in the variables of the age, number of active loans or gender. The complete analysis can be found in the online appendix.

That said, given the lack of access to data from other companies, it is impossible to evaluate if Provident's clients are similar to the general population of creditors at any level. For this reason, the results should be taken with caution if intended to apply to other populations. However, given the consistency with the literature, the possible bias could have affected the estimates, but not to the extent of contradicting the direction or significance of the effects.

Finally, contrary to refinancing repayment studies within the traditional microfinance literature (Armendariz De Aghion and Murdoch, 2000), in this sample, the refinancing incentive does not constitute a powerful tool for getting this institution's clients to repay on time. Our result however is consistent with the finding that individuals that are in the Current group are characterized by short-term impatience. We conclude by highlighting that the preceding results and discussion provide a reason for future research that integrates new personality and cognition theories with traditional microfinance repayment theory. 


\section{References}

[1] Agarwal, S., Mazumder, B. 2013. Cognitive Abilities and Household Financial Decision Making. American Economic Journal: Applied Economics 5:193207.

[2] Aldasoro, B. 2017. Informe Final: Estudio sobre las Tasas de Interés de Microcrédito en México, 2017. Fundación Alemana Servicios. Available at: https:/www.gob.mx/cms/uploads/attachment/file/275439/Estudio_sobre_la s_Tasas_de_Interes_de_Microcredito_en_Mexico.pdf

[3] Almlund, M., Duckworth, A.L., Heckman, J.J., Kautz, T. 2011. Personality Psychology and Economics. In: Hanushek, E., Machin, S., Woessmann, L. (eds), Handbook of the Economics of Education 4: 1-181.

[4] Ameriks, J., Caplin, A., Lehan, J. 2003. Wealth Accumulation and the Propensity to Plan. Quarterly Journal of Economics 118: 1007-1048.

[5] Angelucci, M., Karlan, D., Zinman, J. 2015. Microcredit Impacts: Evidence from a Randomized Microcredit Placement Experiment by Compartamos Banco. American Economic Journal: Applied Economics 7: 151-182.

[6] Armendáriz De Aghion, B., Morduch, J. 2000. Microfinance Beyond Group Lending. Economics of Transition 8: 401-420.

[7] Armendáriz, B., Morduch, J. 2010. The Economics of Microfinance (2nd ed.). The MIT Press: Cambridge, MA.

[8] Arráiz, I., Bruhn, M. and Stucchi, R. 2015. Psychometrics as a tool to improve screening and access to credit. World Bank Policy Research Working Paper No. 7506. Available at: https://ssrn.com/abstract=2698969

[9] Attanasio, O., Augsburg, B., De Haas, R., Fitzsimons, E., Harmgard, H. The Impacts of Microfinance: Evidence from Joint-Liability Lending in Mongolia. American Economic Journal: Applied Economics 7: 90-122.

[10] Augsburg, B., De Haas, R., Harmgard, H., Meghir, C. 2015. The Impacts of Microcredit: Evidence from Bosnia and Herzegovina. American Economic Journal: Applied Economics 7: 183-203.

[11] Baklouti, I. 2013. Determinants of Microcredit Repayment: The Case of Tunisian Microfinance Bank. African Development Review 25: 370-82.

[12] Banerjee, A., Duflo, E., Glennester, R., Kinnan, C. 2015. The Miracle of Microfinance? Evidence from a Randomized Evaluation. American Economic Journal: Applied Economics 7: 22-53.

[13] Basu, K. 2016. A Behavioral Model of Simultaneous Borrowing and Saving. Oxford Economic Papers 68: 1166-74.

[14] Bauer, M. Chytilová, J., Murdoch, J. 2012. Behavioral Foundations of Microcredit: Experimental and Survey Evidence from Rural India. American Economic Review 201: 1118-39.

[15] Becker, A., Deckers, T., Dohmen, T., Falk, A., Kosse, F. 2012. The relationship between economic preferences and psychological personality measures. Annual Review of Economics 4: 453-78.

[16] Bhatt, N., Tang, S. 2002. Determinants of Repayment in Microcredit: Evidence from Programs in the United States. International Journal of Urban and Regional Research 26: 360-376.

[17] Borghans, L., Golsteyn, B., Heckman, J., Humphries, J. 2011. Identification Problems in Personality Psychology. Personality and Individual Differences 43: 972-1059. 
[18] Burks, S. V., Carpenter, J. P. Goette, L., Rustichini A. 2009. Cognitive skills affect economic preferences, strategic behavior, and job attachment. Proceedings of the National Academy of Sciences 106: 7745-50.

[19] Christelis, D., Jappelli, T., Padula, M. 2010 Cognitive abilities and portfolio choice. European Economic Review 54: 18-38.

[20] Cole, S., Paulson, A., Shastry, G. 2014. Smart Money? The Effect of Education on Financial Outcomes. Review of Financial Studies 27: 2022-51.

[21] Cotler, P. 2013. Las tasas activas de interés en el sector microfinanciero de México: Un estudio de caso. Econoquantum Revista de Economía y Negocios 10: 726.

[22] Crépon, B., Devoto, F., Duflo, E., Parienté, W. 2015. Estimating the Impact of Microfinance on those who Take It Up: Evidence from a Randomized Experiment in Morocco. American Economic Journal: Applied Economics 7: 123-150.

[23] Demirgüç-Kunt, A., Klapper L., Singer D., Van Oudheusden P. 2015. The Global Findex Database, Measuring Financial Inclusion around the World. World Bank Policy Research Working Paper Series N WPS7255.

[24] D'Espallier, B., Guérin, I., Mersland, R. 2011. Women and repayment in microfinance: A global analysis. World Development 39: 758-72.

[25] Duckworth, A., Quinn, P. 2009. Development and validation of the Short Grit Scale (Grit-S). Journal of Personality Assessment 91: 166-74.

[26] Eskreis-Winkler, L., Shulman, E., Beal, S., Duckworth, A.L. 2014. The Grit Effect: Predicting Retention in the Military, the Workplace, School and Marriage. Frontiers in Psychology: http://dx.doi.org/10.3389/fpsyg.2014.00036

[27] Frederick, S. 2005. Cognitive reflection and decision making. The Journal of Economic Perspectives 19: 25-42.

[28] Gerardi, K., Goette L., Meier, S. 2013. Numerical ability predicts mortgage default. Proceedings of the National Academy of Sciences 110: 11267-71.

[29] Griffin, D., Husted. B. Social Sanctions or Social Relations? Microfinance in Mexico. Journal of Business Research 68: 2579-2587.

[30] Grinblatt, M., Keloharju, M., Linnainmaa, L. 2011. IQ and Stock Market Participation. Journal of Finance 66: 2121-64.

[31] Heckman, J. 1981. Heterogeneity and State Dependence. NBER Chapters in: Studies in Labor Markets: 91-140.

[32] Heckman, J., Stixrud, J., Urzua, S. 2006. The Effects of Cognitive and Noncognitive Abilities on Labor Market Outcomes and Social Behavior. Journal of Labor Economics 24: 411-82.

[33] Heckman, J., Kautz, T. 2012. Hard Evidence on Soft Skills. Labour Economics 19: 451-64.

[34] Heidhues, P., Koszegi, B. 2010. Exploiting Naivete about Self-Control in the Credit Market. American Economic Review 100: 2279-2303.

[35] Hermes, N., Lensink, R. 2011. Microfinance: Its Impact, Outreach, and Sustainability. World Development 39: 875-81.

[36] Jamshidinavid, B., Chavoshani, C., Amiri, S. 2012. The Impact of Demographic and Psychological Characteristics on the Investment Prejudices in Tehran Stock. European Journal of Business and Social Sciences 1: 41-53.

[37] Kaufmann, C. 2012. "The Influence of Information Presentation, Psychological Mechanisms, and Personal Characteristics of Households' Financial Decision Making." Doctoral Thesis, Universitat Mannheim. 
[38] Kausel, E., Culbertson, S., Madrid, H. 2016. "Overconfidence in Personnel Selection: When and Why Unstructured Interview Information Can Hurt Hiring Decisions.” Organizational Behavior and Human Decision Processes, 137: 27-44.

[39] Klinger, B., Castro, L., Szenkman, P., Khwaja, A. 2013a. Unlocking SME Finance in Argentina with Psychometrics. IDB Technical Note.

[40] Klinger, B., Khwaja, A., Del Carpio, C. 2013b. Enterprising Psychometrics and Poverty Reduction. Springer Science and Business Media.

[41] Laibson, D. 1997. Golden Eggs and Hyperbolic Discounting. Quarterly Journal of Economics 112: 443-77.

[42] Lusardi, A., Mitchell, O. 2014. The economic importance of financial literacy: theory and evidence. Journal of Economic Literature 52: 5-44.

[43] McArdle, J., Smith, J., Willis, R. 2011. "Cognition and Economic Outcomes in the Health and Retirement Survey". In Wise, D. (ed.), Explorations of the Economics of Aging. The University of Chicago Press, Chicago.

[44] McCarthy, Y. 2011. Behavioral Characteristics and Financial Distress. ECB Working Paper 1303, European Central Bank, Frankfurt, Germany.

[45] Meier, S., Sprenger, C. 2010. Present-Biased Preferences and Credit Card Borrowing. American Economic Journal: Applied Economics 2: 193-210.

[46] Nawai, N., Shariff, M. 2012. Factors affecting repayment performance in microfinance programs in Malaysia. Procedia - Social and Behavioral Sciences 62: 806-11.

[47] OECD INFE. 2011. Measuring Financial Literacy: Core Questionnaire in Measuring Financial Literacy: Questionnaire and Guidance Notes for conducting an Internationally Comparable Survey of Financial literacy. Paris: OECD.

[48] Prevoo, T., ter Weel, B. 2015. The importance of conscientiousness for socioeconomic outcomes: evidence from the British Cohort Study. Oxford Economic Papers 67: 918-48.

[49] Roa, M. J., Garrón, I., Barboza, J. 2019. Financial Decisions and Financial Capabilities in the Andean Region. Journal of Consumer Affairs, 53(2), 296323.

[50] Roy, A. 1951. Some Thoughts on the Distribution of Earnings. Oxford Economic Papers, 3: 135-46.

[51] Rustichini, A., De Young, C., Anderson, J., Burks, S. 2016. "Toward the integration of personality theory and decision theory in explaining economic behaviour: An experimental investigation." Journal of Behavioral and Experimental Economics, 64: 122-137.

[52] Van den Berg, M., Lensink, R., Servin, R. 2015. Loan Officer's Gender and Microfinance Repayment Rates. Journal of Development Studies, 51: 124112.

[53] Van Rooij, M., Lusardi, A., Alessie, R. 2011. Financial literacy and stock market participation. Journal of Financial Economics 101: 449-47. 